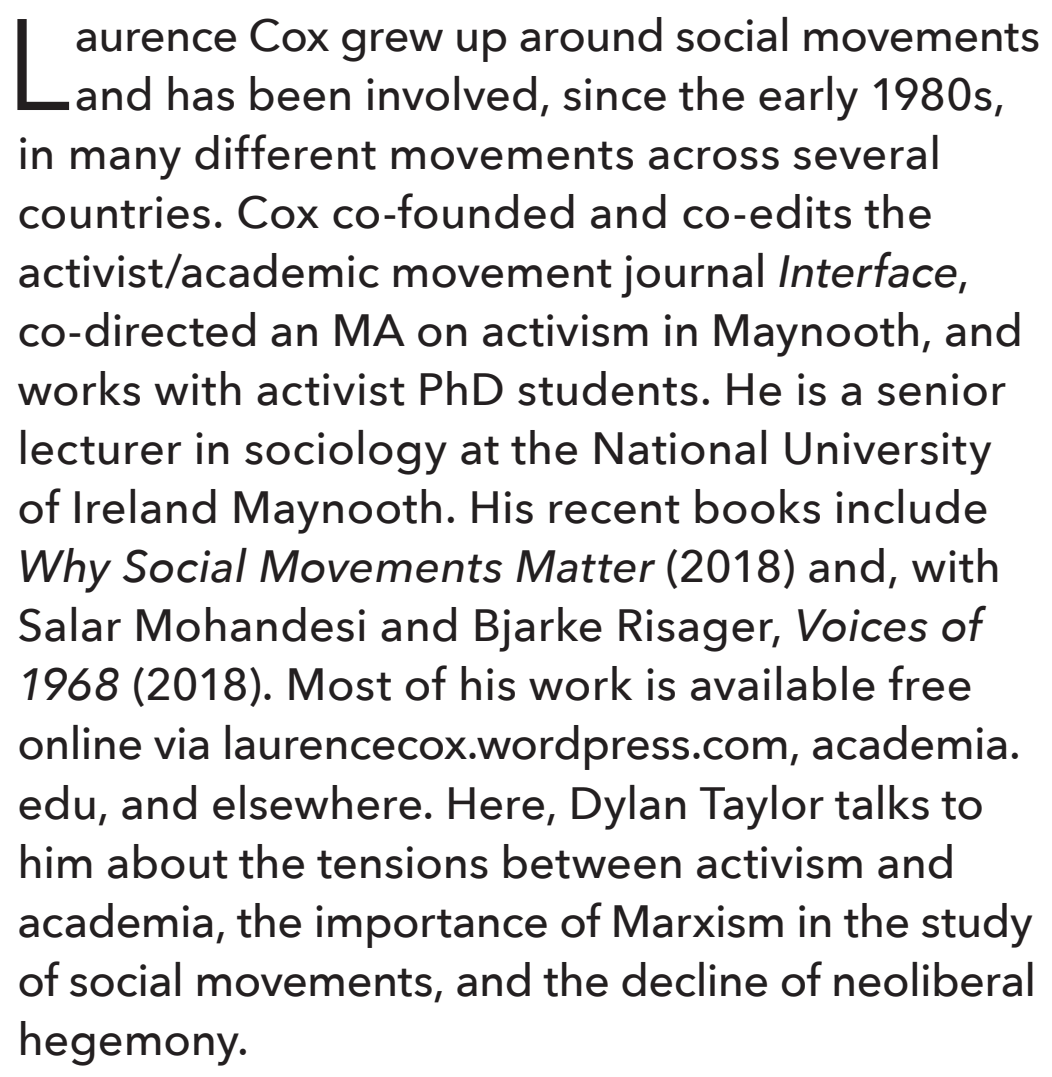


Interview

\section{Struggles from Below in the Twilight of Neoliberalism}

\section{LAURENCE COX}

DYLAN TAYLOR - A recurrent theme in your writing concerns the often fraught relationship of the academy to activism. In a paper co-authored with Colin Barker, you go so far as to say 'academic work is in a sense parasitic on facts mostly produced by movements. ${ }^{1}$ Elsewhere you have argued that 'much of the knowledge now treated as unproblematically academic, including some of its highest-status products, has roots in the efforts of popular movements to contest the status quo.' Could you speak on this theme of movements as knowledge producers, and of the problematic position of the academy in regards to activism? How have you reconciled your own position as a scholar pursuing an academic career with your commitment to activism?

LAURENCE COX - That paper came out of a long dialogue with Colin, where we both recognised that, as activists, we had learned a huge amount from other people in our movements - through internal debate and in pamphlets, magazines, and books. Colin had been an active Marxist for

1 Colin Barker and Laurence Cox, 'What Have the Romans Ever Done for Us?' Paper presented at the $8^{\text {th }}$ Alternative Futures and Popular Protest Conference, Manchester, 2002, http://eprints. maynoothuniversity.ie/428/.

2 Laurence Cox, 'Movements Making Knowledge,' Sociology 48, no. 5 (2014): 954-971. 
decades, so that was one point of reference as a movement-based tradition of political thought. And I knew this partly from the German Left, but also from the radical environmental movement, from being around anarchists, and through feminism. I was struggling to identify a place in the academy where I could usefully work, recognising how much of the radical thought of the 1960s and 1970s had moved into different academic niches (cultural studies, women's studies, environmental studies, development studies, postcolonial studies, and so on), and also seeing the ways in which it had been deformed there, particularly in terms of losing the ability to think systematically about how we organise and what works best, which is fundamental if we want to go beyond simple outrage to actually changing things. I was very interested in the history, documented by both Raymond Williams and Edward Thompson, of the contentious relations between radical, movement-, or community-based thought and 'polite' thought. Of course, these Marxists had partly realised this through their experiences working with 'non-traditional' students, which was also what was shaping me most in the academic workplace, then and later.

The way Colin discussed the difference between activist and academic thought was to say that when Lukács (in his example) analysed a situation it was in order to say to his comrades 'we blew it!' And the ensuing question 'what is to be done?' is also fundamental to any real activist thought. In contrast, academic social movement studies contented itself with an apparently neutral argument that showed how a particular set of events justified its author's theoretical framework. I found, and still find, that at some level outrageous. It is one thing to mock each other when you have both been there, or between comrades, but to stand on the debris of people's lives - which is often what is involved in successful movementsand use it as a way to show how clever you are and how well you can make the sort of noises required by a particular academic in-group — that is pretty repugnant really.

The responses to that paper were very interesting. A lot of people clearly felt personally attacked, as they identified strongly and positively with being an academic in a very unreflective way. But what we actually argued is that all knowledge production takes place within given social 
relationships. ${ }^{3}$ This understanding is inherent in any form of methodology and (if you like it) in the word 'science'. It involves not just acknowledging this reality, but also reflecting on how to shape social relationships so as to produce particular kinds of knowledge. This is precisely what we were talking about: if you reflect on movements in one way, within one kind of social relationship, for one set of social purposes, then this will shape what you do; do things differently and the results will be different. It's really very basic sociology of knowledge or history of ideas.

The other thing that I think was widely missed was an activist sense that we can and should shape the means of intellectual production in line with our purposes. Of course, at any given time there are different sorts of constraints, but these have to be thought about politically. That assessment- 'what kind of social structure am I entering into, and what can I realistically hope to do or change in that context?'-is really basic politics. But simply identifying with whatever structures we happen to find ourselves within and then treating them as an expression of our political self is a very damaging form of alienation. In the academic-activist context, it is far more honest to say, as a number of good activists have said to me, 'I'm really sorry, but now I have to get a permanent job out of this research, and to do that I simply have to publish a certain kind of thing in certain journals and get certain awards, and that determines everything else I do'.

For me, that paper came out of, and responded to, all the non-academic movement intellectuals that I had worked with and drew on, as an honest recognition of their work and against the belief that the only good thinking about movements happens within academia. For at least a decade it was my most widely read and commented on piece, usually by people from activist backgrounds trying to make sense of what was often an intellectual desert in social movement studies. As Thompson puts it, the important thing is to acknowledge that there are vibrant intellectual traditions outside the 'polite' world of the academy. In some ways, it is outrageous that the US scholars who constructed 'social movement studies' as an academic subfield in the 1960s and 1970s could declare terra nullius, that nobody worth

3 See also Laurence Cox, 'Scholarship and Activism,' Studies in Social Justice 9, no. 1 (2015): 34-53. 
mentioning had ever thought about movements systematically or was doing so anywhere else (think of Marxist history, feminism, black studies, postcolonial studies, or cultural studies, for example), and that 'real science' meant referring to them and their work. It is a matter of intellectual selfrespect not to accept that kind of colonial attitude.

It was also part of starting to work with a number of long-time activists, mature students who wanted to research their own movements' practices. That stayed with me and is still, as a dialogue, one of the most important things I do. If we don't start with some clarity and honesty in that dialogue about the differences between knowledge production within movements and the knowledge production in academia, the outcome will not be great.

Beyond that, I then took on the question of seeing how we could open up the space of research on social movements, which in some ways has been the central theme of my work in that area. So both Interface and the MA in activism did that in different ways and on different scales. Intellectually this is also part of the point of working on Marxism and social movements, and of articulating the various different activist and academic traditions of researching movements that the canonised 'social movement studies' tried to dismiss.

Creating the space for activist research, participatory research, or research outside the narrow bounds of canonical 'social movement studies', has been an ongoing struggle in different ways and at different levels. My sense is that, in some contexts at least, things are now a lot more open and dialogical between activism and academia.

You played a founding role in Interface, a journal that explicitly addresses the relationship between activism and the academy. ${ }^{4}$ Could you talk a little about the process of setting this publication up, and its aim? What are the biggest challenges the journal has faced in bringing together academic and activist perspectives and practices?

Interface was a product of a new generation of activists coming out of the anti-capitalist movement at the turn of the millennium-getting involved

4 http://interfacejournal.net. 
with academic research, and reacting strongly both to how the dominant form of social movement studies excluded their own movements' forms of theorising and how it insisted that its questions were the only legitimate ones. It is also no coincidence that this happened in a less rarefied atmosphere, both in the sense of the relative democratisation of higher education after the 1960s and in the context of the precarisation of researchers from the mid-2000s.

We drew on two basic models. One was our own practices in the alterglobalist/anti-capitalist 'movement of movements' of the late 1990s and early 2000s, where we discovered how to work together with people across real distances—not just physical and cultural, but also political and tactical-bringing together different movements around a shared opposition to neoliberalism. We understood how to create a substantial space for internal diversity while still holding a clear common line that defined what we weren't-'one no, many yeses' so to speak. I was particularly proud that we could and can do that: we have eco-feminists and Trotskyists, liberals and autonomists, alternative types and people from the labour movement able to work together; that is quite an achievement.

The other was the model provided by Colin Barker and Mike Tyldesley's Alternative Futures and Popular Protest conference, where the idea for Interface was hatched. Colin and Mike held a very open space, in which a high proportion of participants were also activists, but from very different spaces-old socialists, younger, direct-action eco-anarchist types, feminists, counter-cultural people, and so on. Because there was no status involved, no instrumental reason to be there, people had very real conversations and it was a hugely collegial space. So we tried to capture some of that in Interface.

What we were interested in was substantive knowledge about movements, rather than the particular questions that were allowable or valued within a given discipline. But that issue also applies very much today to radical political traditions, which have often become neoliberalised, turned into niche markets where people tell one another a very particular story about the rest of the world and the chance of learning from other movements is lost. So the phrase 'learning from each other's struggles' is 
a useful one in that context-taking knowledge seriously. And then, of course, Interface had to be genuinely international, with people involved in or studying movements in a given region doing the editing, rather than a metropolitan central committee selecting what it wanted to hear, and to include both the academic and activist worlds.

That last aim was the biggest challenge, given that, if not tied to a particular movement, the natural centre of gravity of such things is likely to be both academic and tied to the founding generation. So we made it a practitioner journal, with one activist and one academic reviewer, and we test our issue themes against this double question: is this useful for movements, and is it intellectually solid? One thing that is particularly good to see is that it hasn't become a generational vehicle-very few of the current editors were there at the start, which is how it should be.

The net effect is that we manage to at least gesture towards this idea of knowledge from and for movements, in the sense that each issue is genuinely diverse in terms of geographical and movement focus, academic and activist emphases, and different political and disciplinary traditions. It is a long way off being perfect, but the hope is that someone can pick it up and at least eavesdrop on conversations about organising that are not normally going on in their own space.

As mentioned earlier, you were involved in the establishment of a Masters programme in community education, equality, and social activism at the National University of Ireland, Maynooth. What led to the foundation of this programme? What kind of programme was it?

This programme came out of the movement of movements, the experience that it was becoming possible again for people in different social movements to work together, and the development of a language and set of practices that made it workable. It also came at a moment when 'social partnership' with the state, which had co-opted every movement in the country except for the peace movement and republicanism, was starting to break down.

So we thought it was the right time to set up a programme for activists, as a practitioner MA geared primarily towards people who were already 
competent activists, but needed time out from day-to-day firefighting to reflect on what they were doing and if it was actually working. We used the strapline 'learning from each other's struggles', because one of the effects not just of partnership with the state, but also of how neoliberalism fragments us into different niche markets, is that we lose the sense of how other movements respond to challenges which are often not very different to ours; we cut ourselves off from a vast amount of learning simply by saying that all we are interested in is this one movement's experience.

There is also the question of how to make real alliances. At a weekend gathering you might not spend much time with people who aren't easy to get on with-but of course those are the alliances you really need, because you don't already have them. If you spend a year in a small group setting with those same people, however, you will get a much better sense of the social realities they are speaking from, what they mean when they say this or that, and how they do things — which are often very different for (say) working class community activists, ecological direct action activists, labour organisers, feminists, trans people, or migrant activists.

Concretely, we offered people a course which focussed not on 'the issues' as many advocacy courses do, but on the practice of organising for example, the history of struggles for equality and the unintended consequences of particular gains (democracy, nation-states, welfare states, cultural liberation); radical popular education as a theory and practice of organising; feminist theory and practice, which was transformative for many activists; and so on-wrapping it all up with a dissertation geared toward improving the practice of students' own movements in a given area.

The course is currently on ice, because with the axing of postgraduate grants there just aren't enough people who can afford to do it. But we did have five years of bringing together some of the best activists in the country across different movements.

In collaboration with Colin Barker, Alf Gunvald Nilsen, and John Krinsky, among others, you have put a great deal of energy into developing a 'Marxist theory of social movements'. What does Marxism have to offer those studying or participating in social movements today? 
My starting point is Thompson's observation that the question is not whether we are on Marx's side, it is if Marx is on our side-meaning on the side of radical activists, the wider world of social movements and communities in struggle, and people who are struggling to survive and resist exploitation, oppression, and cultural stigmatisation. ${ }^{5}$ I've found that a very helpful touchstone. It means leaning away from the false security offered by a particular reading of books or a particular consensus within an organisation and instead asking: 'what can I usefully say to other activists?' And often the answer to that does come out of Marxism. But it's not because it's Marxist that people who are engaged in struggle find it helpful or convincing. As Colin has said, for the first time in many decades Marxism is not widely available to people in movements, and it has to convince them on its own merits rather than through deference to authority. This is actually a far better filter for Marxism than those which operate either in academia or in the sectarian world.

In We Make Our Own History, Alf and I argue that the great strength of Marxism for movements is precisely that it is, in its origins and much of its development, a theory 'from and for movements' ${ }^{6}$ In other words, it comes from people who were involved in, working with, and thinking about a huge variety of revolutions and popular struggles; in some ways it articulates and systematises those very complex and contested processes of movement learning. We don't think Marxism was unique in this, and we invite others to consider how this could be done in relation to other forms of 'frozen movement knowledge' elsewhere in academic theory. I collaborated on a special issue of Interface that tried to draw this out in relation to feminism (and of course, each issue is trying to do that in one way or another).

I do think that Marxism has particular strengths here, not least in the length of experience and the many different debates within it over the years. If you really ground yourself in what Marxists have argued about within movements and parties, you have a solid starting-point for thinking about the struggles of the present. My impression is that Marxists find

5 Edward Thompson, Poverty of Theory (London: Merlin, 1978), 384.

6 Laurence Cox and Alf Nilsen, We Make Our Own History (London: Pluto, 2014). 
it easier to think about popular agency and its complexities than other traditions where the dominant rhetoric is that simply being oppressed/ exploited/culturally stigmatised is the important thing, and it is almost disloyal to ask about the different things people do about it. The Marxist tradition has spent a very long time thinking about the problem that, despite being exploited, workers do not automatically behave radically or even decently_one basic challenge to overcome has usually been forms of particularism which manifest as racism, imperialism, an 'aristocracy of labour', a patriarchal view of things, and so on. The important questions, then, are why that is and how to overcome it.

This is very different from the feeling that if, for example, you acknowledge that very large numbers of women put a lot of effort into maintaining Catholicism in Ireland, you are somehow letting the side down. Of course it was those churchgoers, nuns, housewives, moral entrepreneurs, and vicious defenders of 'respectability' who really let the side down, often at their own daughters' expense-and the real political question is how to overcome this sort of relationship. Similarly, there is nothing 'Marxist' about an identity politics which valorises being 'working class' in a way which is aimed against ethnic minorities, women's, or LGBTQI+ struggles etc. This is really basic to thinking about movements: you can either try to find a side to celebrate and a side to condemn as if it was a gameshow, or you can try to overcome those particularisms and build serious alliances by defeating conservatives in our own movements and making broader alliances. That challenge exists within every movement.

So Marxism has a capacity to think seriously about organised agency and has a long history of different approaches, which is useful for thinking through present-day challenges. One other thing that I think most people working on Marxism and movements are trying to bring out is a serious understanding of the developmental nature of struggle. Struggle is not just something that happens at one level (which is the problem with fetishising any one type of action, be it occupations or political parties, cultural struggle or non-violent resistance); it always has a potential, sometimes considerable, sometimes small, to go further and move beyond the boundaries of its existing social context. But it is important not to see this 
in some idealist way, but rather as arising directly out of material conditions and how people engage with them, and as structured by the process of constructing a movement on more and more powerful scales.

So in the terms Alf and I use, people in given social situations have to develop their own local rationalities for coping, defending what they have, and attempting to change things on a small scale. When there is a major conflict, it is these pre-existing ways of doing things that form the basis for militant particularisms - a particular classed, or gendered, or ethnic, or more commonly all three, way of doing things which erupts as the basis for resistance. To become what we call a campaign, struggles in one place need to find a resonance with struggles elsewhere, or (as sometimes happens) spark them off. A conflict over a single issue in a single place becomes something very different when people start to work on a wider scale of struggle. This involves all sorts of organisational and educational aspects, as well as making allies, so it almost always means remaking the movement. Beyond that, different campaigns are sometimes able to come together around a movement project, a sense of being part of a common struggle against a particular social order or for a certain vision of the world. Obviously, that means something more than a small group in a room-if it isn't felt very widely and deeply, it doesn't have much social purchase. It is these projects that are capable of provoking systemic crises, or even being the basis for a new world.

This underpins what we call the 'ABC of activism': what an experienced or well-read activist knows about what they can do beyond what is immediately obvious, how to avoid reinventing the wheel (which is very costly for movements), and how to take things further, make allies, radicalise the issues, and so on. Very often, if you look into successful movements, you will find people doing this kind of thing. Right now, if we want to convert social majorities into a different kind of society, that perspective is very badly needed.

There is also a wider project of recovering Marxism for movements, beyond the stylised forms it has come to survive in. In that sense, the project is to assert Marxism against Marxisms - to keep asking 'how does this way of organising, this kind of question, this sort of rhetoric actually 
help popular struggles?' Of course, sometimes the answer is not only that it doesn't, but that (in its academic forms) it has no particular intention of doing so.

How does your approach to Marxism and social movements tie into considerations of the role that political parties play (or could play), and, by extension, of the state?

In We Make Our Own History, we give a quick run-through of all the different things 'party' has meant since the moment where Marx and Engels denied that communists formed a separate party opposed to other working class parties (in a book with the word Partei in its title). 'Party' is not a single thing; it is a question, one for which there aren't many very convincing answers right now. A Marxism that ignores this history, and has not seriously thought about what self-declared Marxist parties did to working class struggle in Spain, in Eastern Europe, or in Beijing, for example, does not deserve the name.

The serious question is something like: 'how best can radicals involved in social movements work together for a change greater than would be possible if movements remain fragmented and focussed on local gains alone?' At the moment, if we look at Syriza or Podemos in Western Europe, we are in a period where the previous history of Left experiments with the party has reached some kind of end-point and there is no longer much serious learning from the past. Syriza-as-was stands in a longer tradition of New Left party development and learning. By contrast, Podemos is the initiative of a small (largely academic) group who piggybacked on the much wider indignad@s movement in Spain. After the failure of both approaches, the questions need to be asked again.

What is not helpful here is the sort of school-debate model in which everyone has to have a commitment in principle for or against parties as such. Often, for example, in commentaries on the indignad@s or whatever, we are told in detail what a failure this or that initiative is; but then we are asked to put our faith in parties with absolutely no examination of the actual failure of Left parties in the present. So we compare the difficult 
reality of a massive movement with somebody's imagined Platonic ideal of the Party. This is not comradely debate or even adult thinking.

Clearly we need to find ways of working together. One important thing that should have been learned from the last 150 years of attempts to do so is the importance of honest debate, learning from the past, and creating space for dissent. That would involve taking a good look at the ways in which radical activists already interact, because in this sense 'party-ness', the attempt to identify a way of working together, is a constant feature of popular struggles, and the real question is whether we are doing it well or badly.

If an organisation calls itself a party (or even a movement), but other activists experience it as instrumentalising movement development rather than supporting it, it is not helping popular agency. Similarly, if rather than seriously attempting to develop counter-hegemony (and so putting some of its own corporate interests to one side) it is attempting only to impose its own agenda and stack committees, it is not helping to develop popular agency. The Anglophone opposition between 'movement' and 'party' expresses a massive failure on the part of Left parties in this respect: criticising movements for not seeing how good a bigger party would be is no solution to their own historic failure to convince movement activists that their own party is an effective contribution.

I don't agree that we can usefully talk about parties 'and, by extension, the state'. I would say that this is part of the problem in terms of not thinking more historically about the issue. By historically I mean both a non-caricatured sense of the history of Left parties over the past 150 years in different countries, but also a non-caricatured sense of the changing nature of the state in that period. Again, the challenge is not to assume that there is some non-dialectic 'essence-of-state' to which an 'essence-of-party' is always and everywhere the right answer, without needing to think hard about what these things mean in different times and places.

There are multiple contradictions here. In Western Europe we have just come through a period in which, much as in the mid- $19^{\text {th }}$ century, radical movements were really unable to have a significant and sustained presence in parliaments, the mainstream media, and so on. We are now seeing a situation in which actual Left majorities in parliament are still almost 
impossible in most cases, but where across the European periphery (Greece, Spain, Portugal, Ireland, Iceland) there is no social majority for austerity. Yet despite this, and the legitimacy problems it causes for neoliberalism (broken mandates, technocratic governments, referenda rerun, the 2015 Greek crisis, and so on), the European Union's austerity politics rolls on.

In this situation, the eggs-in-one-basket logic of 'one last push and we can outdo Syriza' is about as helpful as the 'one last push' of the Communist Party of Germany (KPD) in the early 1920s. Insofar as there is a choice to be made in Western Europe, our energies should surely go primarily into building up our strength where we have it-those social majorities and radical movements. I don't mean avoiding parliamentary politics where it is useful or necessary, but rejecting the belief that a terrain which we do not control and where our track record has been consistently poor over many decades is, by definition, the best use of everyone's time and energy.

One key aspect here is internationalism. In practice, the nostalgic Left has become deeply national in its political focus, so that the interest is consistently in single-state experiences like Greece. But even if Syriza had been more determined or circumstances had been better it would have been a very uneven battle. This is what the anti-capitalist movement was pointing towards with its summit protests 15 years ago, and it is no less true today. Our resistance has to be genuinely international, and that immediately runs up against the fact that none of the niche 'internationals', whichever flavour of the Left they represent, are remotely strong enough to mount a successful challenge across many different countries, nor are likely to become so. So an international resistance that is serious about winning has to be much more oriented to difference and alliances for entirely realist reasons.

Where we can learn something very useful about the nature of the state, and our possible relationship to it, is from Latin America and the different relationships between movements and more or less Left-inflected governments over the past 15 years: the experience of the Brazilian Worker's Party (PT) in relation to, for example, the Landless Worker's Movement (MST), and, as we have seen, its inability to turn formal power into real power; the much more radical but very contradictory experiences of Ecuador and Bolivia, where real attempts at reshaping the state to reflect 
the struggles of poor communities and Indigenous populations have been hollowed out by neo-extractivism; the authoritarian turn in Venezuela (no surprise to anyone familiar with the history of the cult of leadership); or the failure that is Left Peronism in Argentina. There is also the question of what international solidarity has looked like in those contexts.

If we turn these party-fetishising clichés on their heads, we need to talk seriously about the Zapatista experience of sustaining a revolution and a very effective dual-power situation over 24 years among some of the poorest and most disadvantaged people on the planet. We also need to pay a lot more attention to the revolution in Rojava, which is absolutely extraordinary under the circumstances. This should not be to repeat the essentialism of presenting these as models that everyone else should follow slavishly, but seriously thinking about what revolution might mean in our own circumstances. That might sound like a refusal to analyse, but one of the obvious things about the actual history of revolutions is how rarely they have been the product of ideologically-directed political parties. Far more commonly they arrive unexpectedly from below and shake up movements and organisations like a house of cards.

It is common for people studying social movements to focus on 'movements from below'-the struggles of those who lack economic decision-making power, privileged access to the state, or cultural privilege - but you, along with Nilsen, also speak of 'movements from above'. What types of movements are these? How would the rise of the alt-Right be characterised here?

The important thing is to see the social world as humanly constructednot just as an intellectual starting-point, but also because it makes it changeable politically. So we have to think about the different forms of collective agency, how human beings coordinate their action to keep the world the way they want it or change it in another direction. Often in the social sciences and Left analysis, we think of 'their' world, the world as it has been created by the agency of the powerful, as the given structure and therefore inaccessible to most human action; relatedly, the tendency is to see movements from below as some kind of occasional blip on that surface. 
This wildly underestimates the scale of popular agency, even though most of that is structured in terms of local rationalities (everyday coping and culture) or militant particularisms (moments of local resistance).

It is also a very first-world way of thinking. When you look at the majority of the world you see that most states were founded through successful resistance to empire. On another level this is the history of the formation of parliamentary nation-states in Europe too. In Ireland, as in much of the world, this process took place within living memory. So we need some term to think about 'movements-become-states'. This is very different to the conservative US model of movements which basically assumes that the polity is fixed and separated off into different fixed 'levels', so that movements appear as some sort of semi-structured level between voter preferences and political parties or interest groups. (It is telling that this approach positions, for example, trade unions or churches as by definition different from movements.)

We need to step back from bourgeois science in a pejorative sense-as a science that eternalises the status quo as ontological categories—and ask: how do human beings organise their agency collectively? Movements from below are those which, lacking wealth, power, or cultural privilege, have to rely on numbers, disruption, cultural creativity, and so on in order to win. That does not in itself make them progressive, although there is a general tendency towards that direction.

Conversely, movements from above are not automatically 'bad movements' (though again there are strong tendencies!); rather, they are movements that have privileged access to the mechanisms of state power, to economic decision-making, and to cultural authority and privilege. For example, fascist violence depends, almost by definition, on tolerance from the state. Fascism invokes both racial/ethnic and gender hierarchies; and when it has come to power it has usually been as the result of an alliance with established right-wing parties (and on occasion foreign states). Finally, in its origins in countries such as Italy, fascists were the paid gunmen defending landowners against peasant occupations, or attacking powerful labour movements on behalf of employers. So that gives a particularly obvious sense of what makes it different in its modes of operation from a 
movement that does not have these kinds of mechanisms to work with and therefore structures itself differently. This, incidentally, is a strength of thinking about agency instead of simply looking at people's structural position: you can start not only to understand (for example) conservative religious women, working class racists, and so on, but also to see how to defeat those movements.

However, there are many different ways in which movements from above can work. Neoliberalism, for instance, basically conquered the institutions from within-the international financial institutions; the boardrooms of multinational corporations; right-wing and then centre-left political parties; and academia and journalism.

A successful movement from above has a lot of work to do, and this is important if we are thinking how to defeat the new authoritarianisms across the world. It has to impose itself both against previously dominant accumulation strategies (Fordism, state socialism, nationaldevelopmentalism), but also against alternative futures from above and below in the kind of crisis involved in its own rise; it has to deal with resistance from below, either offensively or defensively; it has to develop an effective hegemonic strategy that goes beyond coercion and brings a wide range of other social groups on board; and it has to keep the show on the road. So it is no particular surprise when (as we have seen in the EU in particular) fewer and fewer of those running the ship can really be called statesmen or stateswomen, people who understand that the whole arrangement has been constructed and needs to be maintained by work outside and beyond its routines. Rather, more and more of them have mastered the skills of getting on within the apparatus, but are lost when it comes to dealing with things beyond that. The UK Blairites' inability to deal with Corbyn and Momentum, for example, illustrated this wonderfully.

The alt-Right is largely a cultural phenomenon. As we have seen with elements of the Trump team, even when it nominally comes close to power it isn't particularly good at keeping or using it. In a sense it is the Internet version of fascist street thugs: it does useful dirty work for more powerful opponents. As with street fascism, it needs to be countered on that terrain, but we have to keep an eye on the bigger picture and not think that if we 
win an online argument we have really solved things - there will always be useful idiots of this kind.

At present, we are seeing a lot of it in the media and to some extent in academia. As with the much more serious actions of Modi, Sisi, Erdoğan, Putin, Salvini, Órban, and so on, it is important to recognise that there is an experimental aspect to this. If they are successful there will be carpetbaggers who follow them, and academics or journalists who follow the new star; while if we are capable of seeing these authoritarian figures off the same people will loudly proclaim their distance.

More broadly of course, as around Brexit, the alt-Right is a manifestation of the crisis of neoliberalism. The older establishment doesn't really know what to do or how to keep the show on the road, and lacks the capacity to do more than keep doing what it's always done and hope it will be enough. So you get expendable buffoons like Boris Johnson or Nigel Farage in the UK-if they are successful politically, others will row in behind them, but it is no great loss to the powers that be if they are laughed out of existence. It is similar with the alt-Right. If they can 'change the conversation' and invoke the sort of combination of racism, militarism, misogyny, authoritarianism, religious conservatism, anti-communism, and so on that buttressed the Thatcher and Reagan coalitions (for different ends) they will be suitably boosted and rewarded. If not, or if they manage to turn off more people than they convince, the taps supporting them will be closed. So a 'movements from above' analysis is helpful in asking what actual strength these groups have beyond the support of right-wing media, for example. In most places they have little organising capacity on the ground by comparison with more conventional far-Right groups.

You just mentioned that there is a crisis of neoliberalism, and the subtitle of the book you co-authored with Nilsen is Marxism and Social Movements in the Twilight of Neoliberalism. As neo-liberalism can be a slippery term, I wondered if you might briefly define what you mean when deploying this term. Second, what leads you to argue it is in its twilight?

Let's start by talking about 'neoliberalism' linguistically, in terms of actual 
usage, because too often we find a very naïve definitional approach to the term. Around the turn of the century, when the phrase started to be used in our movements, I remember thinking that it wouldn't catch on against the existing vocabulary of cuts and privatisation. What made it catch on was its practical use in the processes of forming the anti-capitalist 'movement of movements', ultimately going back to the Zapatistas, but then also worked out at summit protests, through Parliamentarians for Global Action, social forums, Indymedia, and so on. In this context, its function was to enable alliances by identifying the bigger evil these different movements were fighting against, whether they were organised around labour or ecological issues, Indigenous or peasant struggles, feminism or anti-war activism, and so on. It marked an end to the period where if you personally organised around one issue or dimension of inequality you were constantly told that your main enemy was people who were organising around something else.

So in terms of actual usage, its main meaning was 'capitalism as we know it'. There were two other dimensions to this. One was an awareness that contemporary capitalism had changed massively, as against nationaldevelopmentalism in the majority world or Fordism in the West. The other was understanding that this change hadn't just 'happened'. Rather, there had been a very substantial defeat of the Left, as well as an earlier process of revolt against Fordism culminating in the 'long 1968'. So part of what our book does is to account for this kind of experience-neoliberalism as a movement from above. Our approach to neoliberalism is that it is a form of capitalism systematically imposed, unevenly and on different timescales, after the political and economic crisis of the late 1960s and early 1970s. The question then becomes understanding not what its theologians say, but what the social bases for its success were-in other words, how this new accumulation strategy could become so hegemonic. Because if we understand that, we have a much better idea of what kind of struggle is needed to defeat it.

When we brought the book out, the idea that neoliberalism was in its twilight years provoked much raising of eyebrows by people who had spent their academic lives explaining just how deep-seated neoliberalism is. This is part of the academisation of movement thinking: it rewards 
'contemplative' accounts which present things as uniquely bad, theoretically profound, and almost inaccessible to human agency. But just four years on and the dogs in the street are saying neoliberalism is in crisis. The Trump election and the British referendum to leave the EU have shown that there is no longer a broad consensus for 'business as usual' neoliberalism, and that groups who previously benefitted from neoliberalism now experience themselves as losers. At the same time, the (British) Labour Party and the (US) Democrats, previously safely captured for neoliberalism and the New World Order, have become remarkably restive. France, too, has strayed from course, caught between Nuit Debout and Macron. On the European periphery, neoliberalism has very definitely ceased to be hegemonic; we have there a kind of zombie neoliberalism, while popular struggles have shifted well to the Left. In Germany and other core countries, organised voices that at least claim to be opposed to neoliberalism are more articulated on the far-Right. Meanwhile, the combination of formal democratisation and neoliberal rollout that seemed unstoppable around the world has hit some severe speedbumps and we are seeing new kinds of authoritarianism precisely because countries like Brazil, South Africa, India, Egypt, or Turkey are so politically contested. In other words, there is a crisis of neoliberal hegemony, a crisis of popular consent.

As previously, where '1968' hollowed out popular support for Fordism, state socialism, and national-developmentalism, much of that critical work has been done in the anti-capitalist movement, particularly in Latin America; in global resistance to the 'war on terror'; in all sorts of climate struggles; in Indigenous resistance; and in anti-austerity struggles. So the gradual coming-together of struggles against neoliberalism has been really important, in all sorts of ways.

We are also seeing the long-term failure of the 'war on terror' to cement popular loyalty. And resistance to the war has ultimately been pretty effective: the West has largely had to retreat from land-based warfare (and scratch the plans for conquering one 'rogue state' after another). While that doesn't prevent hugely destructive wars in Yemen, Syria, Libya, and so on, it does means that the US-led Empire is now largely reduced to burning frontier villages rather than extending its territory. Longer-term, of course, 
we are seeing a very quick decline of the New World Order in which the US was supposed to be the world's policeman, the enforcer of neoliberal power.

More widely, predicting the twilight of neoliberalism was actually a fairly easy bet. No form of capitalist accumulation has ever survived all that long. All else being equal, if profit rates boom at the start of a new accumulation strategy given the conditions of the time, the chances are that those conditions will gradually fade. Spoils are only available for a while. Eventually, there is no longer a growing cake to divide up, and flexibility declines massively, because many groups reach the point where the costs of exit no longer outweigh the possible gains from trying something new, or the cost of continuing as normal. Current EU politics illustrates this inability to move. Brexit is a godsend for them because it enables unity without decisions that risk an even more major crisis. This is also why it took neoliberals so long to agree even on a token response to climate change; and what we do have in the form of the Paris Agreement lacks any regulatory bite. But a lot of capital is now threatened by climate change, not least those parts of it associated with fixed investments in low-lying areas (like most cities). So the leadership that Gramsci thought a hegemonic group had to provide to stabilise and reproduce capitalism in a given period is increasingly absent.

I think the most important thing we said was: 'whether neoliberalism is ending is perhaps not the main question we should be asking. Such hegemonic projects have relatively short shelf-lives, induced by their declining ability to meet the interests of the key members of the alliances which underpin them. The real question is one of how much damage neoliberalism will do in its prolonged death agonies; and, even more importantly, what (or more sociologically, who) will replace it and how'? That problem is more rather than less urgent in 2018.

We seem, then, to be entering a particularly tumultuous period in the West. What comfort might we take from neoliberalism being in its twilight when there are so many causes for despair? What developments give you hope?

7 Cox and Nilsen, We Make Our Own History, xiii. 
In a good old-fashioned Marxist way, history gives me hope! At least in relation to the rise of the Right and how liberals prefer a Right that will continue the capitalist project over any kind of mass-based Left. We have been here before, harder and worse, and we won, though not without an incredible amount of suffering. The same is true in terms of mass displacement and foreign wars-nothing here is new, and our current international law on refugees is the product of earlier experiences that the Right are anxious to consign to the past.

Much of our despair comes from false expectations-from wanting people to learn from history because we value education, or even wanting history to have a sort of Whiggish trend upwards despite all the defeats, perhaps in terms of life getting better for 'people like us'. So despair should be a prod to think harder about what we have been emotionally relying on and why.

Climate change and species destruction do represent something qualitatively new, something which threatens the whole species on a much longer timescale, beyond neoliberalism, capitalism, or even class society. Again though, it is important to see where our own reactions come from, because we have to be able to act effectively in difficult circumstances. I am strongly shaped by growing up in the shadow of the second Cold War initiated by Reagan and Thatcher in the early 1980s, when there was a very real possibility that Europe would become the site of a nuclear war. As a teenager this situation was terrifying, not least because it provided an external hook for all sorts of psychological issues. But it is important to remember that we did, in fact, win. The peace movement helped push Reagan to the Reykjavik agreements and to step back from the brink fairly quickly.

One thing I took from that experience was a determination to resist this psychological fixation on external horrors, and to encourage people into a much healthier emotional space, of seeing themselves as potentially effective agents in the world. In this respect, the sort of Left that invests mainly in terrifying people, or in dystopian analyses of neoliberalism and foreign policy, that places social change beyond the reach of popular agency is deeply, fundamentally irresponsible. It is often a mystified response to what is in itself a perfectly healthy alienation from one's own culture of origin and the need to read and communicate with others to find some kind 
of distance from that. The mystification comes when you say implicitly to one another: 'we will validate our own suffering and alienation by adopting a position in which our own superior knowledge of "how bad things are" becomes comforting, because it sets us on a different plane to other people'. And you therefore step away from attempting any wider communication or organisation and from having any effect on the world.

When you look closely at the people who do they are often shilling for an NGO, some left subculture which revolves around consuming opinions, or a sect. They are inviting you not to think too hard about agency because then you might start asking questions about how paying your subscription, following them on Twitter, or being a member is going to translate into radical social change. So what is at stake is having a morally and intellectually serious relationship to our own agency. In this sense, it is about genuinely learning from history, the history of the Left, and not settling for the first or second thing that presents itself because it suits us emotionally. If we don't think seriously about our own motivations, and those of the much larger number of other people for whom what we find psychologically obvious isn't obvious and who therefore act differently, we become prisoners of them.

In terms of hope, talking to people involved in movements, or reading about them, brings up the huge amount of activism that is going on all the time, which, apart from its direct successes, also helps to stop things from getting worse or prevent certain things from being implemented. Of course, it is very easy, almost the default, to only hear about what the other side is doing, but that is desperately disempowering and historically quite naïve.

The world I grew up in was in large part a world of dictatorships. Quasi-fascist ones with death squads and torture chambers in much of Latin America, state socialism across another third of the world, apartheid in South Africa, Marcos in the Philippines, the list goes on. Virtually all of those regimes disappeared, washed away by popular power and, in many cases, revolutions, and I have to explain to students what the Iron Curtain was.

So the list goes on: I live in a country where peasants got the land, where empire had to withdraw, and where nuclear power was defeated. Most of the states on my continent were formed in revolutions-democratic ones 
against monarchies, nationalist ones, socialist ones, anti-fascist ones, and democratic ones again. Like Ken Macleod said, our children eat ice-cream and giggle in the palaces of dead rulers. What gives me hope in this sense is a consistent focus on struggles from below and what they have achieved, with all their ambiguities, contradictions, and limits. The real comparison is with how bad things could be-with the old monarchies, robber-baron capitalism, imperialism, or fascism. The difference there is one we have made. 